\title{
Nutritional Care for older adults in Primary Health Care, from the perspective of health professionals
}

Carolina Lou de Melo? (ID

Maria Angélica Tavares de Medeiros² (1D

Abstract

Objective: to characterize and analyze Nutritional Care (NC) for older adults in Primary Health Care (PHC), identifying how food and nutrition actions (F\&N) were performed and the conceptions that guided them. Methods: a cross-sectional, quantitative and qualitative study was performed in PHC in Santos, São Paulo, Brazil, in two phases: i) a census study was carried out of health units, $\mathrm{N}=28(100 \%)$, with managers who answered a structured interview to assess NC; followed by descriptive analysis. ii) a deeper investigation of this diagnosis was performed, using semi-structured interviews with key informants (interviewees) of care for older adults; being a nutritionist was not a criteria, as there were only three such professionals throughout the entire PHC, and one of the health regions studied was not served by a nutrition professional. The concept of theoretical saturation was used for the sampling plan; content analysis was carried out and the inferences were supported by references of integrality and aging. Results: NC for older adults was highlighted by individual care, predominant in all the services studied (28) (100\%); nutritionists participated in this activity in just nine units $(32.1 \%)$. Theoretical saturation was achieved with nine interviews. According to the discourse analysis, F\&N actions were generic, focused on the treatment of diseases, influenced by negative aspects attributed to aging, there was no planning based on the needs of the territory, and health professionals identified themselves as information transmitters, leaving the responsibility of acting on such information to the older adults themselves. Conclusion: $\mathrm{F} \& \mathrm{~N}$ actions were guided by the biomedical paradigm, fragmented, restricted to disease management, imputing the responsibility for health to the individual themselves. Thus, NC distanced itself from the promotion of healthy aging, weakening its strategic role in the quest for integrated care.

\footnotetext{
Universidade Federal de São Paulo, Programa de Pós-Graduação em Alimentos, Nutrição e Saúde, Santos, São Paulo, Brasil.

2 Universidade Federal de São Paulo, Instituto de Saúde e Sociedade, Departamento de Políticas Públicas e Saúde Coletiva. Santos, São Paulo, Brasil.
}

\author{
Keywords: Primary Health \\ Care. Nutrition Policy. \\ Nutritional Sciences. \\ Integrality in Health. Aging.
}

The authors declare there are no conflicts of interest in relation to the present study.

No funding was received in relation to the present study. 


\section{INTRODUCTION}

Population aging is considered a global challenge for health systems ${ }^{1,2}$. Due to its resolutive capacity at the point of care, the World Health Organization $(\mathrm{WHO})^{1}$ recommends the strengthening of Primary Health Care (PHC) to promote healthy aging ${ }^{3}$.

In Brazil, the National Health Policy for Older Adults (or PNSPI) 4 aims to provide integrated care, coordinated through PHC, in conjunction with the Health Care Network ${ }^{5}$ (or RAS). However, evidence has revealed weaknesses in integrated care, such as difficulty in accessing services, low quality of care and a lack of professionals with training in geriatrics and gerontology. At the same time, specific actions aimed at dealing with harm or injury are prevalent ${ }^{6-8}$.

One of the strategies for addressing this situation and improving the resolutive capacity of PHC in promoting healthy aging is Nutritional Care $^{9}(\mathrm{NC})$, oriented to the specific needs and characteristics of older adults, provided for in the National Food and Nutrition Policy (or PNAN) ${ }^{10}$. NC, together with other measures, can help to improve health services by acting to prevent morbidities classified as PHC-sensitive conditions ${ }^{11}$, such as Chronic Non-Communicable Diseases (CNCDs), which represent an important disease burden among the older population ${ }^{2}$.

The PNAN ${ }^{10}$ is based on improving food and nutrition $(\mathrm{F} \& \mathrm{~N})$ conditions, according to specific individual and collective needs, through interdisciplinary and intersectoral actions to promote health and prevent diseases. Planning care for older adults from this perspective is a potential strategy for overcoming weaknesses in care, focusing on preservation and/or functional recovery and favoring healthy, dignified and autonomous aging ${ }^{12}$.

Although the potential of $\mathrm{NC}$ among the older population is recognized, there are few studies on its role in $\mathrm{PHC}^{13}$. There are also gaps in the identification of intervening factors in F\&N, especially with regard to the planning and management of actions ${ }^{14}$ or the daily provision of services, based on the assumption that concepts of health-disease-care and aging are configured within the micropolitics of work processes $^{15}$.
According to Beauvoir ${ }^{16}$ and Debert ${ }^{17}$, the manner in which society conceives aging is associated with the social-historical process and influences the dynamics of life, including the performance of health professionals. For this reason, such scholars were chosen as the theoretical references of this study, based on the integrality of care $^{18}$, a key principle of both the PNSPI ${ }^{4}$ and $\mathrm{PNAN}^{10}$.

The present study aimed to characterize and analyze NC in PHC for the older population, from the perspective of health professionals, to identify how it is implemented and the concepts that guide $\mathrm{F} \& \mathrm{~N}$ actions for this age group.

\section{METHODS}

A cross-sectional study, with a quantitative and qualitative design, was conducted in PHC in the city of Santos (São Paulo), Brazil.

The quantitative methodology was applied in 2014, in a census study of the diagnosis of F\&N actions in PHC, through interviews with managers of every health unit, $\mathrm{N}=28(100 \%)$, in the four health regions of the city of Santos, which is the largest sea port in Latin America and an important economic hub in the Baixada Santista Region, with a high Human Development Index (HDI= 0.84). This predominantly urban city has approximately 433,000 inhabitants, with an older population of $19.2 \%$, a rate higher than the national figure of $11 \%{ }^{19}$.

For the interviews, which were carried out in the health units, research fellows were selected and received training. The material collected was checked by a field coordinator for possible additional information. The variables used to characterize NC for older adults were: types of $\mathrm{F} \& \mathrm{~N}$ actions (individual, educational, home visits); professionals responsible for such visits and presence of nutritionists in PHC. Descriptive analysis of these data was undertaken.

The qualitative approach was applied in 2016, with data collection performed by the author of this study (at the time a master's student), to broaden the examination of the census findings and understand the context of NC for older adults. In the same health 
regions as in the previous stage, managers were asked to recommend a professional per health service, with minimum experience of two years in caring for older adults, who performed F\&N actions. Such key informants provided data to describe the daily application of these actions. Training in nutrition was not a requirement, as one of the regions did not have a nutritionist available.

For the sample planning of this stage of the study, the concept of theoretical saturation was adopted. This is a procedure used in qualitative research to indicate the point at which data collection can be halted, when the information provided assumes the character of a single body of satisfactory quality, with no new themes of analysis for the study emerging ${ }^{20}$. Semi-structured interviews were conducted based on a script composed of three central categories of the organization of NC: 1) planning and management of health care for older adults; 2) NC for older adults and 3) conceptions about aging and being old. The interviews were audio recorded and transcribed ipsis verbis. To ensure confidentiality, interviewees were identified with the names of flowers.

To support the work, the reflections of one researcher of their experience in the field were recorded in a field diary, a tool that enables dialogue with the reference areas of the study ${ }^{21}$.

The data were organized in accordance with Bardin's content analysis ${ }^{22}$. For each of the categories in the interview script, thematic groups were identified from a rapid, then exhaustive reading. The inferences and interpretations were supported by references to integrality ${ }^{18}$ and socioanthropological aging ${ }^{16.17}$, under the spectrum of the PNAN ${ }^{10}$ and PNSPI.
This survey was approved by the Research Ethics Committee of the Universidade Federal de São Paulo (the Federal University of São Paulo), under opinion No. 1,517,363, and by the Municipal Health Department (MHD) of Santos (São Paulo), in accordance with resolutions 466/2012 and 510/2016. All the participants signed an Informed Consent Form (ICF) before the interview.

\section{RESULTS}

The managers of 28 PHC units participated in the census, of whom 20 were nurses, three were dentists, two were social workers, two were psychologists and one was a pharmacist. As managers, these professionals were responsible for organizing and planning work processes and analyzing service demands and needs, including those related to Nutritional Care. The reports of the managers revealed that $\mathrm{NC}$ for older adults in the PHC units was organized into different types of actions (Table 1).

F\&N actions were performed by a range of professionals, while nutritionists participated in only nine units $(32.1 \%)$, as shown in Table 2 . In PHC throughout the municipal region, there were only three nutritionists, who rotated between three of the four health regions.

Theoretical saturation was reached with nine interviews. The key informants interviewed included five doctors, two nurses, a community health worker $(\mathrm{CHW})$ and a nursing technician. There was no mention of a nutritionist as a reference in care for older adults, although the theme involved NC. Table 3 shows the configuration of the qualitative analysis process. 
Table 1. Percentage distribution of the modalities of Nutritional Care actions for older adults in Primary Health Care units. Santos, São Paulo, Brazil, 2014 (N=28).

\begin{tabular}{ll}
\hline Modalities of actions in Primary Health Care units & $\begin{array}{l}\text { Frequency } \\
\mathrm{n}(\%)\end{array}$ \\
\hline Individual Treatment & $28(100)$ \\
Home Visits & $22(78.5)$ \\
Leaflet Distribution & $16(57.1)$ \\
Fixed groups & $14(50.0)$ \\
Activities in waiting room & $06(21.4)$ \\
\hline
\end{tabular}

Table 2. Health professionals responsible for Nutritional Care for older adults, according to Primary Health Care units. Santos, São Paulo, Brazil, 2014 (N=28).

\begin{tabular}{ll}
\hline Responsible professional for nutritional care in Primary Health Care units & $\begin{array}{l}\text { Frequency } \\
\mathrm{n}(\%)\end{array}$ \\
\hline Doctor & $28(100.0)$ \\
Nurse & $23(82.1)$ \\
Nursing technician & $20(71.4)$ \\
Community health worker & $20(71.4)$ \\
Nutritionist & $09(32.1)$ \\
Social worker & $02(7.1)$ \\
\hline
\end{tabular}

Table 3. Categories, thematic nuclei and registration units for the analysis of Nutritional Care for older adults in Primary Health Care. Santos, São Paulo, Brazil, 2016.

\begin{tabular}{|c|c|c|}
\hline Categories & Thematic nuclei & Registration units \\
\hline \multirow{6}{*}{$\begin{array}{l}\text { Planning and management } \\
\text { of health care for older adults. }\end{array}$} & \multirow{4}{*}{$\begin{array}{l}\text { A fragile structure hampers the } \\
\text { planning and success of health care. }\end{array}$} & No information system. \\
\hline & & Lack of action planning. \\
\hline & & Insufficient training. \\
\hline & & $\begin{array}{l}\text { Lack of professionals, both quantitatively } \\
\text { and in terms of areas of knowledge. }\end{array}$ \\
\hline & \multirow{2}{*}{$\begin{array}{l}\text { Influence of social determinants } \\
\text { on health. }\end{array}$} & Poor socioeconomic conditions. \\
\hline & & Limited social support. \\
\hline \multirow[t]{3}{*}{ Nutritional care for older adults. } & \multirow[t]{2}{*}{ Conceptions about food and diet. } & Food is a predictor of health. \\
\hline & & Food is medicine. \\
\hline & Actions are generic and standardized. & Aimed at CNCDs. \\
\hline \multirow{6}{*}{$\begin{array}{l}\text { Conceptions about aging } \\
\text { and old age. }\end{array}$} & \multirow[t]{2}{*}{ Result of lifestyle. } & Building good habits since childhood. \\
\hline & & $\begin{array}{l}\text { Knowledge and motivation produce } \\
\text { good habits. }\end{array}$ \\
\hline & $\begin{array}{l}\text { Role of health professional in healthy } \\
\text { aging. }\end{array}$ & $\begin{array}{l}\text { Health professional is a transmitter of } \\
\text { knowledge. }\end{array}$ \\
\hline & \multirow{3}{*}{$\begin{array}{l}\text { Negative meanings about aging and } \\
\text { old age. }\end{array}$} & Aging as decay. \\
\hline & & Old age associated with disease. \\
\hline & & Infantilization of older adults. \\
\hline
\end{tabular}




\section{Planning and management of health care for older adults}

The interviewees indicated aspects of daily health practices as care planning. This is most likely due to the absence of an information system, with medical records being the main source of data. Sociodemographic data were recorded on Community Health agent forms and sent to the MHD. There was no system that translated these data into the health profiles of the older population of the region.

“There isn't exactly any specific organization. There are the medical records that we prepare [...] and that go with each consultation [...]. There is nothing in the Health Department, specifically, for it." [Moss Rose].

Data on living and health conditions, collected by the $\mathrm{CHW}$, were restricted to updating the registration and monitoring system for hypertensive and diabetic patients of the Ministry of Health (HiperDia) and to identify individual needs through an active search.

“[...] the health agents, who visit the area, identify the older adults [...]. We call them for consultations according to our needs." [Ipe].

The management of care for older adults was guided by the daily demands of the services. The findings suggested privileging the treatment of diseases, to the detriment of actions planned according to health needs. Individuals who did not experience morbidity or complaints had limited health monitoring.

"[...] patients who are hypertensive, diabetic [...] as they take medication monthly [...] we know that they are being monitored [...]. But what about those who are not [...]? " [Mayflower].

Care guided from the perspective of the disease, and carried out fragmentally, reflects the dynamics of the organizational sphere. Lifelong learning activities, promoted by the MHD, included care for older adults from the perspective of the treatment of $\mathrm{CNCDs}$, reinforcing the association between old age and illness. In addition, there was a lack of professionals from different areas in the teams.
“[...] we have little training related to geriatrics, which deals specifically with caring for older adults [...] we have training related to diseases, not the care of healthy older adults." [Ipe].

"[...] if we were accompanied by psychologists, a social worker [...], nutrition. It would be important.” [Brazil Wood]

The interviewees exposed difficulties in care when faced with individuals in situations of socioeconomic vulnerability and without family or neighborhood support networks. Low social support and income were listed as aspects of the lives of older people that can represent obstacles to the effectiveness of professional practice.

"[...] it is very difficult [...] for these older people who live alone and who are often bedridden and who have no one to look after them." [Ipe].

There are limits to the organization of care for older adults, when such care is restricted to responding to the needs presented within the health service. Strategies were cited to improve treatment, given the need to construct a line of care for this group.

"Integrated care and the family, and not looking only at the patient and the diseases of older adults. Seeing the risks for older adults, prevention is important." [Jacaranda].

\section{Nutritional care for older adults}

The interviewees recognized the role of food in health care for the older adult population and the importance of specific actions based on the socioeconomic reality of the individual.

"Diet, for me, is one of the most important things." [Jacaranda].

"[...] I will not recommend a type of food that I know she won't be able to manage financially." [Calliandra].

Although the interviewees stated that $\mathrm{NC}$ needs to be adjusted to the living contexts of the older 
adults, the practice proved to be standardized and generic.

"[...] body mass index, if the patient already has a pre-existing disease". [Glory Bush].

"[...] guide a healthier diet, but in a generic way". [Moss Rose].

F\&N actions were aimed at the treatment of NCDs, mainly arterial hypertension and diabetes. From the perception of the interviewees, foods acquired the same functionality as medicines and were perceived as good or bad.

"We have the hypertension and diabetes groups [...] that's where we usually guide nutrition more." [Ipe].

"Food is geared towards some type of morbidity, right?!" [Calliandra].

The reasons for the limitations in the understanding of the character of F\&N actions were not restricted to the performance of health professionals who, in general, lacking the ability to perform such activities, responded to immediate demands. Aware of the health conditions presented by older adults, and with a limited number of nutritionists to support such practices, health professionals sought alternatives to care for individuals and fill this gap.

"[...] there was a nutritionist [...] But then she got pregnant, and didn't come back." [Jacaranda]

"I went to get some diets that I had in another unit where I worked and asked to photocopy them! [...] I don't even know who did it. Or when were they were made [...] "[Allamanda]

"We work, get it and carry on. The logic is not seen as a multi-professional exercise" [Moss Rose].

\section{Conceptions about growing old and being old.}

For the interviewees, healthy aging also results from good eating habits throughout life. The idea of the conditionality between time and frequency stood out, along with the idea that if such habits were cultivated since childhood, the individual would be healthy.

"Your diet will determine (...) your body functioning”. [Moss Rose].

"From childhood, you have to prepare yourself for aging. A healthy lifestyle doesn't start at sixty". [Jacaranda].

Two determinants were described by the interviewees to make these good habits possible: knowledge and individual will. The combination of education and motivation would be sufficient, from this perspective, to make an older person healthy.

"[...] education is much, much, much more productive than investment in health". [Moss Rose].

“[...] it's no use having a wonderful team of professionals if the person doesn't want to be helped". [Bougainvillea].

According to the interviewees, their role in promoting healthy aging is to transmit knowledge, as a way of ensuring that the service user incorporates the guidelines received and applies them in their daily lives.

"[...] the most important role is to provide [...] a tool for them to do it (...). The day the patient knows, (...) they will do it." [Jacaranda].

"With these lectures (...) they explain properly (...) the complications of the chronic diseases, right?" [Glory Bush].

For the interviewees, aging healthily requires simple thinking and is dependent on personal momentum. However, the difficulties they exposed revealed barriers to this.

"Older adults who live alone [...] the lack of resources, the network is overburdened, there is a lack of health professionals [...]". [Calliandra]. 
Another factor that hinders healthy aging is the interviewees' attitude towards aging and old age. The results showed that older people were not recognized as autonomous subjects, nor was old age considered a period of latent vitality. On the contrary, they were infantilized, viewed as individuals requiring guardianship.

"[...] an older adult is a child who says what he's thinking". [Jacaranda].

"They are quite aloof, they don't want to obey." Brazil Wood

Interviewees linked aging to decay, disease, and old age to stagnation and frailty.

“[...] they're already a sick population! [...] You just have to treat them, there's nothing else to do." [Allamanda].

"[...] if you don't want to get sick from something, don't get old." [Moss rose].

\section{DISCUSSION}

Few studies have focused on nutrition and aging from the perspective of $\mathrm{NC}$ for older adults, with evidence recorded in terms of nutritional profile, food consumption and nutritional problems, as shown in literature reviews analyzing food and nutrition actions in Brazilian $\mathrm{PHC}^{13,23}$. The innovative character of this research lies in its interdisciplinary approach, supported by the concept of integrated care, supporting the need for qualified $\mathrm{NC}$ as a strategic component for the promotion of healthy aging.

From the characterization and analysis of $\mathrm{NC}$ for older adults, it was identified that F\&N actions, before following the guidelines of the $\mathrm{PNSPI}^{4}$, $\mathrm{PNAN}^{10}$ and international recommendations ${ }^{1}$, were shaped around conceptions which were translated into behavior ${ }^{24}$ that fails to comply with the principles of public policies, resulting in problems in the organization of NC.
The lack of investments in infrastructure, permanent education in geriatrics and gerontology and the contingent deficits in the workforce ${ }^{3.25}$ was reflected in the way in which $\mathrm{F} \& \mathrm{~N}$ actions were carried out. The management of care and organization of NC for older adults was shaped by the biomedical paradigm, eminently curative and restricted to the demands of treating diseases, to the detriment of meeting health needs ${ }^{26}$.

It is necessary to integrate $\mathrm{NC}$ into health planning, as a tool capable of focusing on a given reality, provided that the actions are directed at the heart of the issues ${ }^{26}$. The absence of a situational diagnosis, supported by health surveillance data, hampered the development of F\&N actions. The production of information based solely on professional records, in the act of treatment ${ }^{7,27}$, proved insufficient to identify the magnitude of the existing problems and to elucidate strategies corresponding to the demands of the territory ${ }^{28}$.

A NC information system that combines sociodemographic and health data would support a situational diagnosis, providing elements to organize, monitor and evaluate $\mathrm{NC}$ for older adults. But the scope of this premise is linked to the qualification and training of the workforce and of health services ${ }^{26}$.

The lack of investments to expand the repertoire of health professionals in the area of geriatrics and gerontology ${ }^{1}$, can limit the management of aging and the development of potential opportunities in old age ${ }^{4.7}$. This may have contributed to the association of aging and negative signs, described by the interviewees, for example, when interpreting claims for autonomy as rebellious, infantilizing older adults and considering them as subject to guardianship, which impoverishes the idea of old age ${ }^{16,29}$. The relationship is vertical, something reinforced by the key informants when they assigned health professionals the role of knowledge transmitters.

Thus, F\&N actions took on a prescriptive character, leaving it to the older adults to find the motivation to follow the guidelines received ${ }^{16,17}$. However, the communication of guidelines in themselves has little effect on changing lifestyles, however much they are based on motivational 
strategies ${ }^{10}$. Eating practices are the result of multifactorial determinants ${ }^{10}$ and, in this network, the factor of personal motivation may have the least influence on the construction of healthy practices, differing from the perspective of the key informants.

The prescriptive approach is non-dialogical ${ }^{30}$ and normative, underestimating material aspects for the production of life and disregarding subjectivities and heterogeneity in the forms of aging, contrary to the principles of integrality ${ }^{8,17,18}$.

Awareness of this needs to be extended to all health professionals ${ }^{27}$. However, it is impossible to ignore the tentative insertion of nutritionists in the PHC under study, limiting the scope of $\mathrm{NC}^{25,26,31}$. Despite the interdisciplinary character of such care, nutritionists have specific skills in performing the dialogue between $\mathrm{F} \& \mathrm{~N}$ issues and the various components that involve the healthdisease-care process ${ }^{31}$.

The promotion of healthy aging requires attention to socio-cultural determinants, respect for subjectivity and the quest for autonomy for individuals and the community ${ }^{10,32}$. The key informants demonstrated an understanding of $\mathrm{NC}$ as part of these requirements, as they recognized the influence of life context on healthy aging. However, their practices had little impact on the health needs related to the healthdisease-care process of the older population ${ }^{3.26}$.

This mismatch between discourse and practice portrays the difficulty of implementing a counterhegemonic health system, as observed in the PNSPI ${ }^{4}$ and $\mathrm{PNAN}^{10}$, which defend health as a right and of the need for integrated care. This premise is opposed to the structuring logic of neoliberal capitalism, which is based on the concept of health as a commodity $^{18}$, a product of individual investment ${ }^{17,24}$, and in denying societal contradictions and the role of public policies.

Thus, F\&N actions for older adults were restricted to the treatment of CNCDs, considered a characteristic stigma of old age ${ }^{3}$. From this perspective, the fight against CNCDs may have assumed a pragmatic role in the prevention of old age itself, as food is assigned a role similar to that of medicines. Food can contribute to fighting disease, thus postponing old age. The denial of aging becomes an attempt to denaturalize $\mathrm{it}^{17}$.

This manner of applying NC exposes the need to overcome the treatment of dietary and nutritional issues through the restrictive lens of nutrients ${ }^{10}$, given the complexity involved in the act of eating ${ }^{30}$. The contribution of $\mathrm{NC}$ to healthy aging can be distinguished from the defense of moralizing attitudes, which see individuals according to the types of food they consume ${ }^{26}$. This idea reinforces the blaming of older adults for their food choices, transferring to them the sole responsibility for their aging. This is what Debert ${ }^{17}$ calls the "reprivatization of old age"; thus, possible limitations for constructing healthy aging are condemned as personal carelessness, minimizing the influence of social determinants of health.

It was found that the $\mathrm{NC}$ for older adults in this study lacked planned, coordinated and articulated actions. Actions confined to disease management are unlikely to affect the morbidity and mortality profile of the older population ${ }^{6,12,32,33}$. Consequently, $\mathrm{NC}$ for older adults was characterized by immediate and fragmented actions, with little ability to propose strategies whose aims were the development of autonomy for aging individuals, thus hampering the achievement of integrated care ${ }^{18,29,34}$.

The present study has limitations, mainly due to its regionality and cross-sectional nature. An uncertainty of resources for the promotion of research and a lack of time were issues, in an era when science is under attack, making it impossible to choose methods that would allow the observation and monitoring of F\&N actions in health services, as was the initial plan. However, the central merit of the research is to reveal the emergence of a fostering $\mathrm{NC}$ that promotes healthy aging, in the light of the national guidelines of the Brazilian National Health Service, according to the principle of integrated care.

\section{CONCLUSION}

The reports of health professionals on how Nutritional Care for older adults was provided, in the municipality studied, revealed problems related to the organization and management of such care. The actions of food and nutrition were guided by 
the biomedical paradigm, and were fragmented, being restricted to the management of diseases and influenced by negative conceptions of aging, imputing to the individual the exclusive responsibility for caring for their own health. According to this perception, Nutritional Care has distanced itself from the promotion of healthy aging, weakening its strategic character in the quest for integrated care.
It is hoped that the present study will inspire further research, deepening the reflections exposed and providing evidence to public policy management to support the construction of qualified Nutritional Care for older adults, promoting healthy aging as part of a line of care guided by concepts of integrality.

Edited by: Ana Carolina Lima Cavaletti

\section{REFERENCES}

1. World Health Organization. The world report on ageing and health [Internet]. Geneva: WHO; 2015 [cited 2018 Jan. 15]. Available from: http://apps.who. int/iris/bitstream/10665/186463/1/9789240694811_ eng.pdf

2. Chang AY, Skirbekk VF, Tyrovolas S, Kassebaum NJ, Dieleman JL. Measuring population ageing: an analysis of the Global Burden of Diseases Sttudy 2017. Lancet Public Health [Internet]. 2019 [cited 2020 May 16];4:e159-67. Available from: https:// www.thelancet.com/pdfs/journals/lanpub/PIIS24682667(19)30019-2.pdf

3. Placideli N, Castanheira ERL, Dias A, da Silva PA, Carrapato JLF, Sanine PR, et al. Avaliação da atenção integral ao idoso em serviços de atenção primária. Rev Saúde Pública [Internet]. 2020 [cited May 13];54(6):1-14. Available from: https://www.revistas. usp.br/rsp/article/view/165861/158742

4. Brasil. Ministério da Saúde. Portaria no 2.528, de 19 de outubro de 2006. Aprova a Política Nacional de Saúde da Pessoa Idosa. Saúde Legis. 2006. Available from: https://bvsms.saude.gov.br/bvs/saudelegis/ gm/2006/prt2528_19_10_2006.html

5. Mendes EV. As redes de atenção à saúde. $2^{\mathrm{a}}$ ed. Brasília, DF: OPAS; 2011. Capítulo 2, As redes de atenção à saúde: revisão bibliográfica, fundamentos, conceito e elementos constitutivos; p. 61-83.

6. Nivestam A, Westergren A, Petersson P, Haak M. Factors associated with good health among older persons who received a preventive home visit: a cross-sectional study. BMC Public Health [Internet]. 2020 [cited 2020 May 16];20(688):1-7. Available from: https://bmcpublichealth.biomedcentral.com/track/ pdf/10.1186/s12889-020-08775-6

7. da Motta LB, de Aguiar AC, Caldas CP. Estratégia Saúde da Família e atenção ao idoso: experiência em três municípios brasileiros. Cad Saúde Pública [Internet]. 2011 [cited 2015 Jan. 15];27(4):779-86. Available from: http://www.scielo.br/pdf/csp/ v27n4/17.pdf
8. da Luz LA, Futino MI, da Luz EA, Martins GM, Barbosa EPM, Rocha LM. Avaliação das ações estratégicas na atenção à saúde do idoso em Unidades Básicas de Saúde de Teresina-PI. Rev Bras Med Fam Comunidade [Internet]. 2012 [cited 2016 Jun.15];7(22):20-6. Available from: https://rbmfc.org. $\mathrm{br} / \mathrm{rbmfc} /$ article/view/379/453

9. Moura ALSP, Recine E. O nutricionista e o cuidado integral do indivíduo com excesso de peso na atenção básica. Rev Nutr [Internet]. 2019 [cited 2020 May 16];32:e190008. Available from: https://www.scielo. br/pdf/rn/v32/1678-9865-rn-32-e190008.pdf

10. Brasil. Ministério da Saúde, Secretaria de Atenção à Saúde, Departamento de Atenção Básica. Política Nacional de Alimentação e Nutrição [Internet]. Brasília, DF: MS; 2013 [cited 2015 Apr. 03]. Available from: http://bvsms.saude.gov.br/bvs/publicacoes/ politica_nacional_alimentacao_nutricao.pdf

11. Carlos MJ, Cavaletti ACL, Caldas CP. Hospitalization of the aged due to stroke: An ecological perspective. Plos ONE [Internet]. 2019 [cited 2020 Sept. 23 ];14(8):e0220833. Available from: https://journals.plos. org/plosone/article?id=10.1371/journal.pone. 0220833

12. Schenker M, da Costa DH. Avanços e desafios da atenção à saúde da população idosa com doenças crônicas na Atenção Primária à Saúde. Ciênc Saúde Colet [Internet]. 2019 [cited 2020 Apr. 15];23(4):136980. Available from: https://www.scielo.br/pdf/csc/ v24n4/1413-8123-csc-24-04-1369.pdf

13. Canella DS, da Silva ACF, Jaime PC. Produção científica sobre nutrição no âmbito da Atenção Primária à Saúde no Brasil: uma revisão de literatura. Ciênc Saúde Colet [Internet]. 2013 [cited 2017 Jul. 10];18(2):297-308. Available from: https://www.scielo. br/pdf/csc/v18n2/02.pdf

14. Pereira KCR, de Lacerda JT, Natal S. Avaliação da gestão municipal para as ações da atenção à saúde do idoso. Cad Saúde Pública [Internet]. 2017 [cited 28 Aug 8];33(4):e00208815. Available from: https://www.scielo. br/pdf/csp/v33n4/1678-4464-csp-33-04-e00208815.pdf 
15. Franco TB, Merhy EE. Cartografias do trabalho e cuidado em saúde. Tempus [Internet]. 2012 [cited 2017 Sept. 03];6:151-63. Available from: https://app. uff.br/slab/uploads/Cartografias_do_Trabalho_e_ Cuidado_em_Sa\%C3\%BAde.pdf

16. Beauvoir S. A velhice I: a realidade incômoda. Dantas HL, tradutora. Vol. 1. São Paulo: Difusão Europeia do Livro; 1970.313 p.

17. Debert GG. A reinvenção da velhice: socialização e processos de reprivatização do envelhecimento. São Paulo: Fapesp; 2004.

18. Pinheiro R, Mattos RA, organizadores. Os sentidos da integralidade na atenção e no cuidado à saúde. $8^{\mathrm{a}}$ ed. Rio de Janeiro: UERJ/ IMS; 2009.

19. Instituto Brasileiro de Geografia e Estatística. Censo: sinopse [Internet]. 2020 [cited 2020 Aug. 12]. Available from: https://cidades.ibge.gov.br/brasil/sp/santos/ pesquisa $/ 23 / 25207$ ?tipo $=$ ranking\&indicador $=25186$

20. Nascimento LCN, Souza TV, Oliveira ICS, Moraes JRMM, Aguiar RCB, Silva LF. Theoretical saturation in qualitative research: an experience report in interview with schoolchildren. Rev Bras Enferm [Internet]. 2018 [cited 2020 Aug. 12];71(1):228-33. Available from: http:// dx.doi.org/10.1590/0034-7167-2016-0616

21. Weber F. A entrevista, a pesquisa e o íntimo, ou: por que censurar seu diário de campo? Horiz Antropol [Internet]. 2009 [cited 2020 Feb. 22];32:157-70. Available from: http://www.scielo.br/pdf/ha/v15n32/ v15n32a07.pdf

22. Bardin L. Análise de conteúdo. Reto AL, Pinheiro A, tradutores. São Paulo: Edições 70; 2011.

23. Pereira TN, Monteiro RA, Santos LMP. Alimentación y nutrición en atención primaria en Brasil. Gac Sanit [Internet]. 2018 [cited 2020 Aug. 12];32(3):297303. Available from: http://dx.doi.org/10.1016/j. gaceta.2017.08.004

24. Bauman Z, May T. Aprendendo a pensar com a sociologia. Werneck A, tradutor. Rio de Janeiro: Zahar; 2010.

25. Shrimpton R, du Plessis LM, Delisle H, Blaney S, Atwood SJ, Sanders D, et al. Public health nutrition capacity: assuring the quality of workforce preparation for scaling up nutrition programmes. Public Health Nutr [Internet]. 2016 [cited 2020 May 15];19(11):2090-2100. Available from: https://doi. org/10.1017/S136898001500378X

26. Rigon SA, Schmidt ST, Bógus CM. Desafios da nutrição no Sistema Único de Saúde para construção da interface entre a saúde e a segurança alimentar e nutricional. Cad Saúde Pública [Internet]. 2016 [cited 2020 May 07];32(3):e00164514. Available from: https://www.scielo.br/pdf/csp/v32n3/1678-4464csp-32-03-e00164514.pdf
27. Vitorino SAS, da Cruz MM, de Barros DC. Validação do modelo lógico teórico da vigilância alimentar e nutricional na atenção primária em saúde. Cad Saúde Pública [Internet]. 2017 [cited 2020 May 14];33(12):e00014217. Available from: https:// www.scielo.br/pdf/csp/v33n12/1678-4464-csp-3312-e00014217.pdf

28. dos Santos CM, Barbieri AR, Gonçalves CCM, Tsuha DH. Avaliação da rede de atenção ao portador de hipertensão arterial: estudo de uma região de saúde. Cad Saúde Pública [Internet]. 2017 [cited 2020 Sept. 06];33(5):e00052816. Available from: https:// www.scielo.br/pdf/csp/v33n5/1678-4464-csp-3305-e00052816.pdf

29. Damaceno DG, Chirelli MQ, Lazarini CA. A prática do cuidado em instituições de longa permanência para idosos: desafio na formação dos profissionais. Rev Bras Geriatr Gerontol [Internet]. 2019 [cited 2020 Apr. 22];22(1):e180197. Available from: https:// www.scielo.br/pdf/rbgg/v22n1/pt_1809-9823-rbgg22-01-e180197.pdf

30. Botelho FC, Guerra LDS, Pava-Cárdenas A, CervatoMancuso AM. Estratégias pedagógicas em grupos com o tema alimentação e nutrição: os bastidores do processo de escolha. Ciênc Saúde Colet [Internet]. 2016 [cited 2020 May 14];21(6):1889-98. Available from: https://www.scielo.br/pdf/csc/v21n6/14138123-csc-21-06-1889.pdf

31. Neves JA, Zangirolani LTO, de Medeiros MAT. Evaluation of nutritional care of overweight adults from the perspective of comprehensive health care. Rev Nutr [Internet]. 2017 [cited 2018 Sept. 10];30(4):511-24. Available from: https://www.scielo. br/pdf/rn/v30n4/1415-5273-rn-30-04-00511.pdf

32. Mantovani EP, de Lucca SR, Neri AL. Associações entre significados de velhice e bem-estar subjetivo indicado por satisfação em idosos. Rev Bras Geriatr Gerontol [Internet]. 2016 [cited 2020 Apr. 22];19(2):203-22. Available from: https://www.scielo. br/pdf/rbgg/v19n2/1809-9823-rbgg-19-02-00203.pdf

33. Veras RP, Oliveira M. Envelhecer no Brasil: a construção de um modelo de cuidado. Ciênc Saúde Colet [Internet]. 2018 [cited 2020 May 15];23(6):192936. Available from: https://www.scielo.br/pdf/csc/ v23n6/1413-8123-csc-23-06-1929.pdf

34. Cervato-Mancuso AM, Vincha KRR, Santiago DA. Educação alimentar e nutricional como prática de intervenção: reflexão e possibilidades de fortalecimento. Physis [Internet]. 2016 [cited 2017 Aug. 10 2017];26(1):225-49. Available from: https://www.scielo.br/pdf/physis/v26n1/0103-7331physis-26-01-00225.pdf 